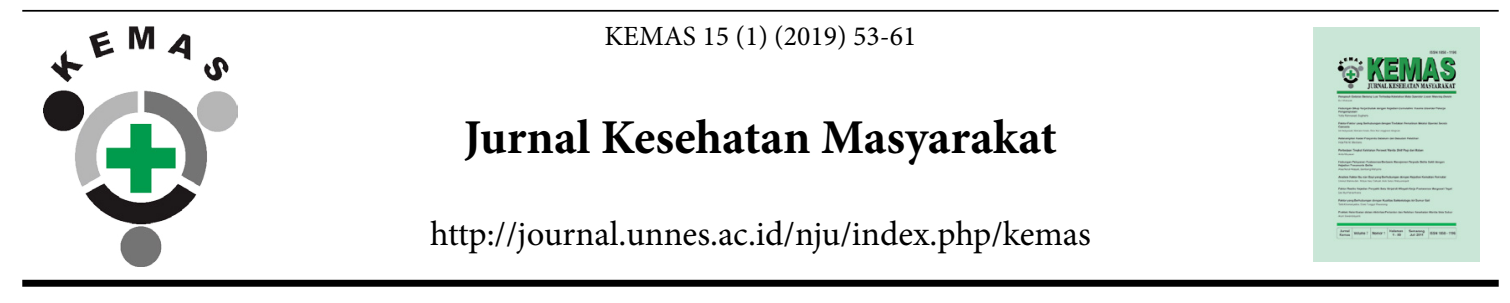

\title{
Study of Contraceptive Management in National Health Insurance Era at Central Java
}

\author{
Sri Winarni ${ }^{1 \bowtie}$, Najib $^{2}$, Martini $^{1 凶}$, Urip Tri Wijayanti ${ }^{2}$ \\ ${ }^{1}$ Department of Biostatistics and Population Study, Public Health, Diponegoro University, Indonesia \\ ${ }^{2}$ Research and Development of National Family Planning Coordinating Board of Central Java Province, \\ Semarang, Indonesia
}

\section{Article Info \\ Article History: \\ Submitted September 2018 \\ Accepted April 2019 \\ Published July 2019 \\ Keywords: \\ acceptance, contra- \\ ceptive, distribution, \\ planning, storage \\ DOI \\ https://doi.org/10.15294/ \\ kemas.v15i1.15820}

\begin{abstract}
Healthcare facilities partners of BPJS have not been synchronized with registered healthcare facilities. Empty stock of contraceptives, excessive storage of contraceptives, and disruption in distribution chain are still seen in the last three years. The purpose of this study was to identify issues related to the management of contraceptives (planning, acceptance and storage). The research used mixed method (quantitative and qualitative approach). The samples were 30 first-level healthcare facilities in Jepara and Wonosobo regencies. There was no planning at provincial level because contraceptive planning activities was regulated by the central health office. Planning of contraceptive requirement at regency/city level was conducted by provincial health office. The acceptance mechanism in the Province involved inventory officer while at health facilities it was performed by Family Planning program manager. Observation of storage rooms for contraceptive in Jepara found that there was no temperature recording device, excess stock of contraceptive injections and pills, absence of thermometer in the storage room, non-functional air conditioning, no separation between storage of hormonal and non-hormonal contraceptive, and there was no distance between pallet and the wall. Meanwhile, contraceptive storage space in Wonosobo has met the Standard Operating Procedure (SOP).
\end{abstract}

\section{Introduction}

Health insurance is a guarantee of health protection for participants to improve health care and to meet the basic health needs, and is provided to everyone who has paid contributions or fees required by the government (BKKBN,2015)

Every residents of Indonesia is required to become a participant of JKN in order to cross subsidize so that the financial barrier to healthcare services in the society can be eliminated. JKN was also intended to realize quality control and cost control in health services, strengthen primary health care and its referral system, and prioritize promotivepreventive efforts. Effective promotivepreventive efforts will reduce the incidence of disease and reduce healthcare costs. Family planning $(\mathrm{KB})$ services are part of promotivepreventive efforts.(BKKBN, 2011)

The family planning program's goal is to control fertility that requires a quality contraception method to improve sexual and reproductive health. Its implementation is influenced by availability of resources, community's perspective on reproductive health and $\mathrm{KB}$ services, and the use of contraceptives. (BKKBN,2015) 
The policy and provision of contraceptive services support facilities include the provision of adequate contraceptive tools in every healthcare facilities and networks. Increased assurance of the availability of contraceptives through the procurement and distribution of contraceptives has been set in the Regulation of BKKBN number 286 / PER / B3 / 2011 on guidelines on the implementation of acceptance, storage and distribution of contraceptives and non-contraceptives of national population and family planning programs. (Bawing et al.,2017) It was published three years before the JKN program was implemented in Indonesia.

Based on the Minister of Health of the Republic of Indonesia regulation number 71 of 2013 on health services on national health insurance $(\mathrm{JKN})$ in Article 19 mentioned that contraceptives are not covered by BPJS Health but the cost is covered by BKKBN. According to the BKKBN chief regulation number 185 / PER / E1 / 2014 it is mentioned that the contraceptive tools provided by BKKBN for JKN participants are condoms, combined pills, 3 monthly injections, implants, and intrauterine devices (BKKBN,2015). The contraceptive tools are distributed to the first level and more advanced healthcare facilities, as long as they have a Cooperation Agreement (MCC) with BPJS Health and registered in the BKKBN SIM through the registration card of KB health facility.

Based on the results of studies conducted by Puslitbang KB and KS in 2015 in 4 provinces (Lampung, West Java, Central Kalimantan and East Nusa Tenggara) on "Study of Implementation of Family Planning Services in National Health Insurance", the data between healthcare facilities partners of BPJS Health has not been synchronized with healthcare facilities registered in K/0/KB.(Kementerian Kesehatan Republik Indonesia,2014)

Therearealsoproblemsinthemanagement of contraceptives program provided by the government in the last 3 years such as a vacuum of contraceptives (stock out), the excess supply of contraceptives in the warehouse of provinces and regencies, and the disturbed distribution chain. (Purwaningsih,2012) The results of the assessment of the supply chain of the family planning program conducted by the JSI
Research and Training Institute in cooperation with BKKBN in 11 regencies / cities at 2016 found that $45 \%$ of the sampled healthcare service facilities had a vacuum of contraceptives for at least one of the contraceptives provided by BKKBN and hence could not provide all of the available methods to the community. There are 29 health care facilities out of stock for injections and $21 \%$ out of stock for implants.

The vacuum of contraceptives, according to the findings of JSI Research and Training Institute, was caused by several conditions including: delays in procurement processes at Central level, weaknesses in inventory management, weaknesses in Logistics Information System Management (LMIS), weaknesses in transport and distribution systems, inadequate storage of contraceptives, and lack of coordination, communication and human resource accountability. Weakness in inventory management in the form of contraceptive distribution system based on the target service (push system) occurred because the calculated number of contraceptives need was not responsive to the changing pattern of consumption. Meanwhile, the weakness in Logistics Information System Management (LMIS) occurred due to the absence of stock recording or improper stock recording at the facility. (Oktriyanto,2016) (Paramita Boni Lestari,2017)

The problems are not separate from the mechanism of acceptance, storage and distribution / distribution of goods including maintenance and security, as well as recording and reporting of contraceptives. The mechanism is a series of activities in an effort to maintain the continuity of the availability of contraceptive tools to support the operation of family planning programs at every levels. Based on the description above, it is necessary to identify problems related to the management of contraceptives, including planning, acceptance and storage starting from the central, provincial, district / city level down to the First Level Health Facility (FKTP). Data on the results of this study is necessary to improve the management of contraceptives in JKN era.(Panjaitan \& Goenawi, 2014).

\section{Method}

This research used mixed method with 
quantitative and qualitative approach. Selection of district / city samples was done purposively considering the high vacuum of contraception device. The selected regencies / cities were Jepara Regency and Wonosobo Regency. From District / City, 30 first-level health facilities (FKTP) (including public health center, private doctor practice, primary level clinics and type D hospitals) were taken. Quantitative data collection was conducted via smartphones (ODK program) while the qualitative data was obtained from in-depth interviews. In-depth interviews were conducted by researchers to targeted contraceptive managers from the Central BKKBN, Provincial BKKBN, district family planning officers, and First-Level Healthcare Facilities. The contraception storage rooms at provincial, district and primary healthcare facilities were observed.

The enumerator was tasked with collecting forms in the form of monthly reports F / II / KB Clinic from each healthcare facility visited during January 2016 to June 2017 (18 months) for photocopying. The photocopied form was submitted by the enumerator was subsequently analyzed for the occurrence of empty stock or excess stock or participation in family planning at the Healthcare Centers.

The instrument used was 6 forms. Form 1 was filled by managers of the family planning program at the provincial level (Province BKKBN), form 2 was filled by managers of the family planning program at the district level, form 3 was filled by Head of the District / City Health Office, form 4 was filled by officers at the first level health facility (quantitative data collection), form 5 was filled by first-level health facility officials (qualitative data collection), form 6 was filled by the provincial and district / city contraceptive warehouse staff. Matrix 1 and matrix 2 are the matrix of the results of calculations F / II / KB.

\section{Results and Discussion}

Planning needs of contraceptives in Central Java Province has never been planned. All needs have been arranged and supported by the Center. Provinces were never asked to plan. Both the number and types of contraceptives have been determined by the Center. As for the number and types of contraceptives given by the center based on the potential data available in Central Java, the achievements in the previous year for new KB participants, and how much the need for active family planning participants should be continued. For details, the provincial planning does not know clearly because the planning party does not participate in the planning process.

The planning of contraceptives in regency/city was different from province level. Regency/City requested based on needs. There are 5-10 regencies / cities that planned their own contraceptives procurement using APBD funds (Purwaningsih, 2012). Contraception

Table 1. Planning of contraceptives based on routine needs at healthcare facilities

\begin{tabular}{lll}
\hline Planning Variable & Regency/City & \\
\cline { 2 - 3 } Planning of routine contraception needs at Wonosobo Jepara & Wonosobo & Jepara \\
\cline { 2 - 3 } healthcare facilities & 3 & $\mathrm{f}$ \\
\hline The calculation was done by OPD KB Regency/City & 23 & 9 \\
The calculation was done by the health facility itself & 1 & 14 \\
Combination of 1 and 2 & & 9 \\
\hline
\end{tabular}

Table 2. Planning based on the source of contraceptives in healthcare facilities

\begin{tabular}{llllll}
\hline Planning Variable & \multicolumn{4}{l}{ Regency/City } \\
\hline \multirow{2}{*}{ Contraceptive tools source } & \multicolumn{4}{l}{ Wonosobo } & \multicolumn{3}{l}{ Jepara } \\
\cline { 2 - 5 } & Yes & No & Yes & No \\
\hline OPD-KB Regency/City & 27 & - & 25 & - \\
Public Health Office Regency/City & - & 27 & - & 25 \\
Self-procurement (facility's budget) & 2 & 25 & 2 & 23 \\
Other sources & - & 27 & - & 25 \\
\hline
\end{tabular}


tool needs plan in Wonosobo district was conducted for one year, planning of this requirement in planning part and area of $\mathrm{KB}$, planning section then arranged the database while $\mathrm{KB}$ field compiled contraception needs using the formula on Perka BKKBN No. 287 which is calculating the minimum and maximal requirement. The following is contraceptive planning based on routine need and source of contraception in health facility of Wonosobo and Jepara Regencies.

The calculation of routine contraceptive needs planning in Wonosobo Regency was mostly conducted by the healthcare facilities themselves, while for Jepara regency the calculation was done by combined calculation by OPD KB regency/city and by the healthcare facilities themselves.

For planning based on source of contraception, both in Wonosobo regency and Jepara regency the largest source was OPD-KB Regency / City. Although most contraceptives were obtained from OPD-KB Regency / City, there were healthcare facilities that procured their own contraceptive tools.

The receiving mechanism in the Province involved the PPHP (Receiving Committee). PPHP has been involved since 2016. Upon receiving the goods, random checking was done. PPHP will record the status of goods received, whether they were in good condition or not. Record of damaged goods was compiled by stating the batch number and the origin of the damage with a photograph attached. Recording was done manually. If there were damages outside the random sample, damage recording was still performed. Generally, the damaged goods percentage was lower than $10 \%$. After the acceptance process is completed, the goods were sent to provincial warehouse. The process of goods acceptance from PPHP to the warehouse lasts for 1 day at most. (Panjaitan \& Goenawi,2014)

The acceptance of contraception at the provincial level comes from the central BKKBN without going through a third party. However, in the city / regency level, the acceptance mechanism can be done through distributors / partners to the committee acceptance OPD KB of the regency / city. Acceptance of contraceptives in Jepara and Wonosobo regencys was generally similar, contraceptive devices were sometimes taken by the material Treasurer to the province, or sometimes also through the dropping process of the province. When contraceptives were taken directly to the province, it will be received directly by material treasurer. When the goods were dropped, the material treasurer will also check the administrative requirements, condition of the contraceptives (both quantity and quality of the contraceptives) and then confirm to the superior of the material treasurer and make a report of the event. The goods were then stored inside the warehouse.(Oktriyanto, 2016)

$$
\text { Acceptance mechanism of }
$$

contraceptives in health facilities in Jepara regency was through contraceptive receivers. Recipient officers will re-examine the quality and quantity of contraceptives, meanwhile the examination of administrative completeness was done by the family planning program manager at the health center / clinic. Similar process also took place in Wonosobo regency. Inspection of administrative completeness was also performed by program manager officer / management officer of contraception device in health facilities. According to the

Table 3. Compliance admittance of contraceptives in regencies/cities

\begin{tabular}{lll}
\hline Planning Variable & Regency/City & \\
\cline { 2 - 3 } Accurate acceptance of contraceptives & Wonosobo & Jepara \\
\hline According to the needs & 26 & $\mathrm{f}$ \\
\hline Not as needed & 1 & 24 \\
\hline Contraceptives received are damaged / expired & & 1 \\
\hline Occurred at least once & 25 & 10 \\
\hline Never occurred & 2 & 15 \\
\hline
\end{tabular}


results of contraceptive checks, the acceptance of contraceptives in Wonosobo and Jepara regencies has been largely in accordance with the needs. This can be seen from table 1.3 of contraceptive acceptance in Regency / City

Although acceptance of contraceptives is considered appropriate but there were still stock void for some types of contraceptives and contraceptives with broken / expired conditions between January 1, 2016 and June 2017.

Storage of contraceptives was performed in such a way in order to maintain and secure the existing contraceptives. With the appropriate storage standardization, the quality of contraceptives can be maintained so as to minimize contraceptive failure.

Central Java Provincial contraceptive equipment warehouse is located separately with the representative office of BKKBN province. The warehouse was managed by a material treasurer with pharmaceutical background and hence had an adequate knowledge about the standard contraceptives storage. All contraceptives were placed on a wooden pallet for storage. Contraceptives will be arranged to show their expiry date and was stored using FEFO (First Expired First Out) system, meaning that goods that will expire fastest will be placed at the front to be issued first. There was a special treatment for hormonal contraceptives, which will be stored in a cool room or air conditioned room with a temperature of $<250 \mathrm{C}$.

Based on Head of BKKBN Regulation no. 287 / PER / B3 / 2011 on guidance on the implementation of contraceptive and noncontraceptive tool planning / contraceptives planning, contraceptive needs planning conducted at each level must be proposed to the level above, ie contraceptive needs planning at the province level will be submitted to the

Table 4. The duration and type of contraceptives with stock void

\begin{tabular}{lll}
\hline Variable Length of Time and Type of Stock Void Contraception & Regency/City & \\
\hline The duration and type of IUD contraceptives with stock void & Wonosobo & Jepara \\
\cline { 2 - 3 } Not empty & f & $\mathrm{f}$ \\
1 month & 25 & 25 \\
2 months & - & - \\
3 months & - & - \\
$>3$ months & - & - \\
\hline The duration and type of implant contraceptives with stock void & & - \\
\hline Not empty & 25 & 25 \\
1 month & 1 & - \\
2 months & - & - \\
3 months & - & - \\
$>3$ months & 1 & - \\
\hline The duration and type of injection contraceptives with stock void & 25 & 25 \\
\hline Not empty & 24 & 22 \\
1 month & 2 & 2 \\
2 months & - & - \\
3 months & - & - \\
$>3$ months & 1 & 1 \\
\hline The duration and type of pills contraceptives with stock void & & \\
\hline Not empty & 27 & 25 \\
1 month & - & - \\
2 months & - & - \\
3 months & - & - \\
$>3$ months & - & - \\
\hline The duration and type of condom contraceptives with stock void & & \\
\hline Not empty & 22 & 25 \\
1 month & - & - \\
2 months & 1 & - \\
3 months & 2 & - \\
$>3$ months & 2 & - \\
\hline & & \\
\hline
\end{tabular}


Table 5. Observation of warehouses

\begin{tabular}{|c|c|c|c|c|c|c|c|}
\hline \multirow{2}{*}{ No } & \multirow{2}{*}{$\begin{array}{l}\text { Observation of warehouses } \\
\text { Condition of storage space }\end{array}$} & \multicolumn{2}{|c|}{$\begin{array}{l}\text { Provincial } \\
\text { warehouse }\end{array}$} & \multicolumn{2}{|c|}{$\begin{array}{l}\text { Jepara } \\
\text { Regency }\end{array}$} & \multicolumn{2}{|c|}{$\begin{array}{l}\text { Wonosobo } \\
\text { Regency }\end{array}$} \\
\hline & & Yes & No & Yes & No & Yes & No \\
\hline & a. Clean & $\mathrm{V}$ & - & $\mathrm{V}$ & - & $\mathrm{V}$ & - \\
\hline & b. Dry and free from water leaks & $\mathrm{V}$ & - & $\mathrm{V}$ & - & $\mathrm{V}$ & - \\
\hline & c. There is a functioning AC & $\mathrm{V}$ & - & - & V & $\mathrm{V}$ & - \\
\hline & $\mathrm{d}$. There is a functioning fan & $\mathrm{V}$ & - & $\mathrm{V}$ & - & $\mathrm{V}$ & - \\
\hline & e. There is adequate ventilation & $\mathrm{V}$ & - & $\mathrm{V}$ & - & $\mathrm{V}$ & - \\
\hline & f. There is a temperature monitor (space thermometer) & $\mathrm{V}$ & - & - & $\mathrm{V}$ & $\mathrm{V}$ & - \\
\hline & g. There is a daily temperature monitoring recorder & & $\mathrm{V}$ & - & $\mathrm{V}$ & $\mathrm{V}$ & - \\
\hline & h. There is a stock card of contraceptives & $\mathrm{V}$ & - & $\mathrm{V}$ & - & $\mathrm{V}$ & - \\
\hline \multirow[t]{6}{*}{2.} & Placement of contraceptives & & & & & & \\
\hline & a. Separated from insecticides & $\mathrm{V}$ & - & $\mathrm{V}$ & - & $\mathrm{V}$ & - \\
\hline & b. Separated from chemicals and other hazards & $\mathrm{V}$ & - & $\mathrm{V}$ & - & $\mathrm{V}$ & - \\
\hline & c. Protected from direct sunlight & $\mathrm{V}$ & - & $\mathrm{V}$ & - & $\mathrm{V}$ & - \\
\hline & d. FEFO and FIFO systems are in place & $\mathrm{V}$ & - & $\mathrm{V}$ & - & $\mathrm{V}$ & - \\
\hline & e. Expired/damaged contraceptives are separated & - & - & - & - & - & - \\
\hline 3. & Room temperature at observation & \multicolumn{2}{|c|}{$24{ }^{\circ} \mathrm{C}$} & \multicolumn{2}{|c|}{$26^{\circ} \mathrm{C}$} & \multicolumn{2}{|c|}{$24{ }^{\circ} \mathrm{C}$} \\
\hline
\end{tabular}

center, OPD KB Regency/City made a plan which will be submitted to the province, etc. The planning of family planning services at the central level is prepared nationally and based on situational analysis, including proposals from provinces and outcomes of family planning services in previous years, regional and global agreements and objectives that are in line with the objectives of the health and family planning RPJMN.

However, in reality, the planning is top-down planning, not bottom-up planning. As a result, the province has never planned contraceptives needs. All needs were supported by the Center. Thus far, the province has never been asked to plan. All contraceptive needs planning was already regulated by the center, including the number and types of contraceptives. As a result, the supply contraceptives in warehouses is not suitable with the actual regional needs (Astuti,2015). There are some contraceptives with excess stock and some with empty stock. Central BKKBN made the plan for Provinces based on existing potential couples of childbearing age data in Central Java and Province's achievements in the previous year (new FP participants, need for active family planning).

Furthermore, for planning needs of contraceptives in regency / city is calculated by Province. Calculation of formula for need of contraception of Regency / City based on PPM (Community Demand Estimation) and RKA done by KB field. Planning of contraceptive needs in health facility is done by $\mathrm{KB}$ department based on number of acceptors of PA and PUS in their region. Health facilities themselves do not plan contraceptives needs for one year because it was planned by OPD KB. Although the lower structure of both health facilities and District Family Planning OPD plan earlier, the results will change after the goods were dropped from the center, hence it can be difficult to control the required amount at times.

Plans made was also related to the existing inventory in the Provincial warehouse, such as planning needs of contraception in Wonosobo district. The planning section of contraceptives in Wonosobo planned the contraceptives needs for one year. Planning of this level required the involvement of the planning section to arrange the planning base data and KB section to compile contraception needs by using the formula in Perka BKKBN no. 287 to calculate the minimum requirement and maximal requirement. However, the number of contraceptives sent also depended on the supply of the Provincial Warehouse. 
If there were excessive contraceptive tools in the Province, the Regency/City will receive dropping contraceptives, even if it was not the types of contraceptives requested by the Regency/City. There are several contraceptives provided independently by healthcare facilities. This was because the syringe on the contraceptive device that was dropped from the Center, were disliked by the acceptors.

BKKBN activities in the preparation phase include mapping by requesting proposals for provincial needs through the Provincial BKKBN Representative; analysis, proposal and drafting of action plan by taking into account the proposals of the Provincial BKKBN Representative and the availability of contraceptive service supporting facilities in BKKBN. According to the head of BKKBN, in terms of acceptance of contraceptives, PPHP will receive contraceptives and check its condition. For provincial BKKBN, the receiving mechanism at Province level involved PPHP (Receiving Committee). PPHP has been involved since 2016. Upon receiving the goods, random checking was done. PPHP will record the status of goods received, whether they were in good condition or not. Record of damaged goods was compiled by stating the batch number and the origin of the damage with a photograph attached. Recording was done manually. If there were damages outside the random sample, damage recording was still performed. Generally, the damaged goods percentage was lower than $10 \%$. After the acceptance process is completed, the goods were sent to provincial warehouse. The process of goods acceptance from PPHP to the warehouse lasts for 1 day at most.

Upon receiving the goods, it is necessary to examine the quantity, quality and requirements of contraceptive tools and whether the BHP received was in accordance to the receipt documents set forth in the proceedings of contraceptive tools acceptance. (Indonesia,2014). Acceptance of contraceptives in Jepara and Wonosobo districts were similar, however, at times the contraceptives were taken by the material Treasurer to the province, or sometimes through the process of dropping from the province. When contraceptives were taken directly to the province, it will be received directly by material treasurer. When the goods were dropped, the material treasurer will also check the administrative requirements, condition of the contraceptives (both quantity and quality of the contraceptives) and then confirm to the superior of the material treasurer and make a report of the event.(Anwar,2011)

The good were subsequently stored inside the warehouse. There was no separate committee to receive the goods; it was only received by the material treasurer. Recording was still performed manually and not synchronized healthcare facilities, OPD Regency and the Province related to demand and acceptance. Information about contraceptives availability in both provinces, district OPDs, and updated health facilities can be found online. This is because there were several regencies/cities with differences in the result between manual and online recording system.(Dieleman et al. 2018). Warehouse information system will improve the accuracy, efficiency and effectiveness. (SuryantoTommi,2016)

Acceptance mechanism of contraceptives in health facilities in Jepara regency was through contraceptive receivers. Recipient officers will re-examine the quality and quantity of contraceptives, meanwhile the examination of administrative completeness was done by the family planning program manager at the health center / clinic. Similar process also took place in Wonosobo regency. Inspection of administrative completeness was also performed by program manager officer / management officer of contraception device in health facilities.(Glasier \& Gebbie,2005)

In general, the storage of contraceptives in provincial warehouses meets SOPs as set forth in Perka BKKBN number 286 / PER / B3 / 2011 on guidelines on the implementation of acceptance, storage and distribution of contraceptive and non-contraceptive tools of KKB programs. The contraception tools should be arranged on pallets not more than 2 meters tall, distance between pallet and wall of jakar is $30 \mathrm{~cm}$. The arrangement of contraceptives should visibly show the identity of the goods such as the batch number mark, the year of production and the expiry date. (Rakhi \& Sumathi,2011). Contraceptives that will expire fastest should be placed at the front or at the top 
so that they will be issued first. The standard room temperature for IUD and condoms is maximum $25^{\circ} \mathrm{C}$ whereas for pills, injection and implant maximum $15^{\circ}-25^{\circ} \mathrm{C}$.

Injection contraceptives and implants require a cooler room temperature, hence they can be stored together. To maintain the quality of contraception, the lamps used is incandescent. However, there was no daily record of store room's temperature (Mukasa et al.,2017). Recording of room temperature is important in order to ensure the quality of contraception tools. The warehouse was experiencing excess stock of contraceptives, and injectable contraceptive pill was not arranged according to SOP such as exceeding the maximum height requirement and not placing the goods on pallet because all of the pallets were used.

Storage of contraceptives in Jepara warehouse was not much different from the province. There were several conditions that did not comply with the SOP such as no thermometer (and hence no daily temperature record), air conditioning in the storage room for injection and implants did not work, hormonal and non-hormonal contraceptives were stored together, no distance between pallet and the wall and some contraceptives were even attached to the wall.

Wonosobo regency had a better contraceptive storage compared to those at the province and Jepara District. The storage largely met the contraceptive equipment storage SOP. Contraceptives were placed on pallets, protected from sunlight, implants and injection were stored in one room with a minimum temperature of $25^{\circ} \mathrm{C}$, had a temperature gauge and daily temperature monitoring book. For security, doors were equipped with iron tralis. The storage system used FEFO system. FEFO system (First Expire First Out) is a process of expenditure of contraceptives and noncontraceptive devices based on expiry date, contraceptives which expire earlier must be issued first.

Storage places of contraceptives in health facilities varied widely. Several facilities stored some of their contraceptives inside KIA room where KB services took place in order to facilitate $\mathrm{KB}$ service to acceptors. However, there was also a separate storage of contraception in the medicine warehouse. According to Perka BKKBN No. 286 on guidance on the execution of acceptance, storage and distribution of contraceptive and non-contraceptive devices of KKB program, cleanliness must be maintained, which means that storage space must be cleaned from anything that can cause damage (dust, chemicals, and unused contraceptives). Hormonal contraception must be stored in a maximum room temperature of $25^{\circ} \mathrm{C}$. Contraceptives must be stored in such a way to ease family planning service without undermining contraception quality.

\section{Conclusions}

The mechanism of planning of contraceptives was conducted from top to bottom. The province has never done any planning because the center already conducted the planning, causing the existence of nonconformity with the existing stock.

Planning needs of contraceptives in districts / cities was conducted by the Province. Calculation of contraceptive needs was done using PPM (Community Demand Estimates) and RKA conducted by KB field. Planning at health facilities level was done by FPD based on the number of acceptors PA and PUS. However, after receiving dropping from the center, the amount received were not appropriate because it also depended on the existing stock in the provincial warehouse. Therefore, such planning was still not enough to control the needs.

The acceptance mechanism in the Province involved the PPHP (Receiving Committee). The examination was performed randomly. PPHP will record the status of received goods. Damaged goods were recorded by stating the batch number of the goods and the origin of the damage, with a photograph attached.

Acceptance of contraceptives in health facilities were carried out by contraceptives/ program managers while the examination of administrative completeness was conducted by the family planning program manager at the health center/clinic.

In general, the storage of contraceptives in the provincial warehouse already met the SOP. However, there was no temperature monitoring and there were excess stock types 
of pills and injections and the contraceptive arrangement did not met the SOP.

Storage of contraceptives in Jepara warehouse did not met the SOP such as no thermometer in storage room, nonfunctional AC, hormonal and non-hormonal contraception were stored in one room and no distance between pallet and the wall.

Storage of contraceptives in warehouse of Wonosobo Regency has met the SOP. The storage system used is the FEFO system.

\section{Acknowledgements}

The authors would like to express their gratitude to the National Family Planning Coordinating Board who has supported this research through funding.

\section{References}

Anwar, 2011. Manajemen Rantai Pasokan (Supply Chain Management) Konsep dan Hakikat. Jurnal Dinamika Informatika, 3(2).

Astuti, D., 2015. Faktor-faktor yang berhubungan pemilihan alat kontrasepsi suntik. jurnal Artikel, XI(2), pp.233-243.

Bawing, P., Wilopo, S.A. \& Padmawati, R.S., 2017. Analisis pelaksanaan kebijakan program keluarga berencana : studi kasus di Malinau. BKM Journal of Community Medicine and Public Health, pp.817-822.

BKKBN, 2015. Peraturan Kepala BKKBN Nomor 185/PER/E1/2014 tentang Pedoman Penyelenggaraan Pelayanan KB dalam JKN dan MOU antara BKKBN dengan BPJS.

BKKBN, 2011. Rencana Strategis (Renstra) BKKBN Tahun 2010-2014 untuk Pembangunan Kependudukan dan Keluarga Berencana.

Dieleman, J.L. et al., 2018. Trends in future health financing and coverage: future health spending and universal health coverage in 188 countries, 2016-40. The Lancet, 391(10132), pp.1783-1798.
Glasier, A. \& Gebbie, A., 2005. Keluarga berencana dan kesehatan reproduksi. Jakarta: EGC, 15(September), pp.252-259.

Kementerian Kesehatan Republik Indonesia, 2014. Pedoman Manajemen Pelayanan Keluarga Berencana Direktorat., Jakarta.

Mukasa, B. et al., 2017. Contraception supply chain challenges: a review of evidence from lowand middle-income countries. The European Journal of Contraception \& Reproductive Health Care, 22(5), pp.384-390. Available at: https://www.tandfonline.com/doi/full/10.10 80/13625187.2017.1394453.

Oktriyanto, 2016. Penyelenggaraan pelayanan keluarga berencana dalam jaminan kesehatan nasional. Jurnal Ilmu Keluarga dan Konsumen, 9(2), pp.77-88.

Panjaitan, R.M. \& Goenawi, L.R., 2014. Pengelolaan Alat Dan Obat Kontrasepsi Di Badan Kependudukan Keluarga Berencana Nasional ( Bkkbn ) Provinsi Sulawesi Utara. , 3(3), pp.230-234.

Paramita Boni Lestari, S.H., 2017. Analisis Fungsi Manajemen Logistik di Badan Pemberdayaan Masyarakat dan Keluarga Berencana Kota Surabaya. Jurnal Administrasi Kesehatan Indonesia, 5(1).

Purwaningsih, S.S., 2012. The Decentralization of the Family Planning Program: Challenges and Issues, the West Kalimantan Province Case (Bahasa Indonesia). Jurnal Kependudukan Indonesia, VII(2), pp.109-125.

Rakhi, J. \& Sumathi, M., 2011. Contraceptive methods: Needs, options and utilization. Journal of Obstetrics and Gynecology of India, 61(6), pp.626-634.

SuryantoTommi, 2016. Perancangan Sistem Informasi Gudang pada Perwakilan Badan Kependudukan Keluarga Berencana Nasional. Jurnal Sistem Informasi dan Teknologi Informasi, 5(1), pp.25-34. 